\title{
Call for Activation of Simulation Modules for Nursing Students' Achievement and Satisfaction of Normal Labor: A Quasi- Experimental Study
}

\author{
Noha Hassan Abd-Elfattah ${ }^{1}$, Galal Ahmed EL-Kholy², Amal Ahmed Hassan ${ }^{3}$, \\ Hanan Elzeblawy Hassan ${ }^{*}$ \\ ${ }^{1}$ Assistant lecturer of Maternal and Newborn Health Nursing, Faculty of Nursing, Beni-Suef University, Egypt. \\ ${ }^{2}$ Professor of obstetrics \& gynecology, Faculty of Medicine, BenhaUniversity, Egypt. \\ ${ }^{3}$ Professor of Obstetrics and Women's Health Nursing department, Benha University, Egypt. \\ ${ }^{4}$ Assistant Professor of Maternal and Newborn Health Nursing, Faculty of Nursing, Beni-Suef University, Egypt. \\ *Corresponding Author: Hanan Elzeblawy Hassan, Assistant Professor of Maternal and Newborn \\ Health Nursing Department, Faculty of Nursing, Beni-Suef University, Egypt, Email: nona_nano_1712@yahoo.com
}

\begin{abstract}
Background: Simulation is a potentially powerful teaching approach that engages nursing students and requires them to use critical thinking and clinical reasoning, and provides an opportunity for reflective learning and integration of the student's knowledge.
\end{abstract}

Aim of the Study: was to study effect of simulation on students' achievement and satisfaction in normal labor modules.

Design: A Quasi experimental study was used.

Setting: This study was conducted at maternity nursing lab \& lecture class in the faculty of nursing Benha University.

Sample: Purposive sample of 60 students were included in the study subjected for simulation achievement in labor modules and 60 students were included in control group in the study subjected.

Data Collection Tool: The of data collection were self-administered questionnaire sheet, observational checklist, students' satisfaction with learning method and media for the module of labor (Noelle mannequin and videos).

Result: There was a highly statistical difference regarding students' practical skills during process of labor including perineal care, abdominal examination, vaginal examination, handling, assessment of fundus, placental examination and newborn physical assessment of both phase of assessment.

Conclusion: Simulated delivery room classes were an effective training approach; they provide students with practices that result in a significantly higher practical achievements and higher satisfaction scores compared to the conventional training.

Recommendations: Maternity nursing students should be provided by variety of simulation-based education on maternity nursing skills to increase level of performance, satisfaction, and self-confidence.

Keywords: Simulation, Nursing simulation, Achievement, Normal Labor, Satisfaction

\section{INTRODUCTION}

Simulation models have been regarded as the most prominent innovation taking place in nursing education over the past decade. They have been used as a pedagogical method for training nursing students'. A simulator is a potentially powerful teaching approach that engages nursing students' and requires them to

ARC Journal of Nursing and Healthcare use critical thinking, practical and clinical reasoning, and provides an opportunity for reflective learning and integration of the student's knowledge. ${ }^{[1]}$ Simulation is an educational strategy that can be used to support the process of clinical education. It can be helpful in improving students' self-esteem through provide an opportunity to practice in a risk-free environment. ${ }^{[2]}$ 
A simulator is the imitation of the operation of a real-world process and/or system over time. ${ }^{[3]}$ Simulator is recognized as a vital part of nursing clinical educations by nursing institutions. ${ }^{[4]} \mathrm{It}$ can provide a safe environment for students to learn the clinical practice, it allows students to put knowledge into practices, recognize mistakes prior to entering the career field. In addition, it can also communicate and interact with the learners. ${ }^{[5]}$

Simulations are used in nursing education in the military, nuclear power, and aviation. It is also a recommended in teaching/learning strategy supported by several studies. Although in the past twenty years ago simulation models have been becoming more integrated into the nurses' and physicians' education, they haven't been as well integrated into the development of skills for practicing nurses. Simulations have demonstrated several benefits in nursing in preparation of newly graduated nurses for the practice environment. ${ }^{[6]} \mathrm{A}$ clinical simulation in nursing education can be used for many purposes, for examples, as teaching strategy or for assessment and evaluation. However, one of the most important reasons that educators use simulations for assessment and evaluation of learning should be integrated into the large process of planning, implementation, assessing and evaluating learning. ${ }^{[7]}$

The purpose of simulation is to achieve specific goals related to learning or evaluation. Simulator doesn't replace the need for learning in the clinical practice setting but allows the student to develop their assessment, critical thinking and decision-making skills in a safe and supportive environment. ${ }^{[8]}$ Simulations ensure uniformity of learning experiences and put students in a situation in which need to be active and in control of learning. As a result, students will develop knowledge and skills according to their own needs. This stimulating environment and freedom of learning increases student motivation and interest in learning and developing confidence in abilities. ${ }^{[9]}$ This also allows for the assessment and evaluation of the student performance, whereby if the student demonstrates a mistake, inaccurate assessment or slow clinical decision making, the student has the opportunity to learn from the experience. The primary aim of simulation is to help the student nurse to achieve competence, linking their theoretical knowledge with clinical practice. ${ }^{[10]}$ However, the other advantages of simulation are: (1) allow learners to attain knowledge, skills in a safe controlled environment; (2) provide opportunity to learn from experience make mistakes without risk to patients; (3) increase speed to learning skill and developing competence; (4) assure similar learning experience for each student for given scenario, reduce variability in teaching learning process; (5) promote patient safety and prevent medical errors; (6) allows for immediate feedback related to performance; (7) allow quick implementation to educate best practice procedure or remediate skills. ${ }^{[1]}$

Simulation models can take many forms, including human patient simulator manikins and/or standardized patients, virtual and computer-based simulations, simulation was done to teach psychomotor skills, or role play. Simulations provide a rich learning opportunity for students to integrate theory with practice while making real-time clinical decisions in an environment that poses no risk to patients. Simulations create a transformational learning experience for all nursing students and provide diverse perspectives on caring for patients across the continuum of care. ${ }^{[12]}$

As laboring and birthing process is a lifechanging event for every woman. Nurses need to be respectful, available, encouraging, supportive and professional in dealing with women. The nursing management for labor and birth should include assessment, and care, advocacy, and support for a woman. This care usually based on an assessment of maternal and fetal status during labor through promoting comfort and providing intervention measures. ${ }^{[13]}$ So, simulations use continues to expand in nursing education, specifically at the undergraduate level. Graduate nursing students can also benefit from simulation activities. Graduate nurse educator students' exposure to clinical teaching issues may be limited; therefore, simulation provides a realistic, safe environment for students to practice the development of the teacher role. This manuscript provides ideas for planning, implementation, and suggestions for simulation technology used in the training of nurse educators for their role in clinical teaching. ${ }^{[14]}$

Satisfaction has been widely used in the lay measurement of quality of services. Satisfaction rating reflects the personal preferences and the client's expectations. ${ }^{[15]}$ Simulations as a strategy for clinical education promote student satisfaction with their learning and improve self- 
confidence. A simulation will prepare the student to for real-life experience and speed the transition to a professional career. ${ }^{[16]}$ It builds confidence and self-efficacy. Clinical simulation proves a crucial role in the field of maternal/child health and allows nursing program to assess students' competency. ${ }^{[17]}$

A framework is needed when designing simulation activities. Simulation theory takes into all consideration of the simulation activity to ensure best practice and participant outcomes. The original framework has four components that include background, design, simulation experience and outcomes. Each component is a $\operatorname{cog}$ in an interactive dynamic diagram. Each portion impacts the whole, causing a reaction within a learning activity; thus consideration needs to take in each of the four components when creating simulation activities. ${ }^{[18]}$

Jeffries describes clinical simulation as "a phenomenon defined as a perceived situation, a process, a group of events and a group of situation". To understand the phenomenon of a clinical situation, this mid-range theory is intended to provide guidance for the implementation of simulation and future research in studying simulation phenomenon and also contribute to the science of nursing education. The concepts of Jeffries include the context (which encompasses all of the conceptual factors that impact every aspect of the simulation), the background, the design elements, the simulation experience, and the outcome of the simulation. The outcomes of the simulation may relate to the participant, the patient, and the system. ${ }^{[19]}$

\subsection{Significance of the Study}

Simulation models would be important to optimization, greatly improving our understanding of the system necessary to formulate optimization problem. This creates further opportunities to transfer learning from fields outside health care. ${ }^{[20]}$ Furthermore, simulation put students' in a classroom to learn on their own or lecturing to them in a classroom. This is eminently sensible by the same taken classroom. Simulation removes the risk from these complex skills learning without stress of the real situation and helps students acquire the teaching skills through the role play in the classroom. ${ }^{[21]}$ Staff should work to improve and streamline processes in the Nursing Simulation Lab. Students evaluate their simulation experience after every simulation day and after selected learning activities. This data is used to identify areas of opportunity to improve our lab and simulation program. Staff feedback is solicited to ensure scenarios are realistic and align with current practice. ${ }^{[22]}$ Normal labor module is considering the most important module in maternity nursing course. In fact, not all students can get a chance to observe, manipulate and intervene normal labor in the hospital, so simulation can play this role by putting these students in the virtual situation. Simulations have become a means to bridge classroom instruction and actual clinical environments. As there is no previous study regarding simulation was conducted at obstetrics and gynecology department, faculty of nursing Benha University, so, this study will be conducted to apply simulation for teaching the labor module and study its effect on student's achievement.

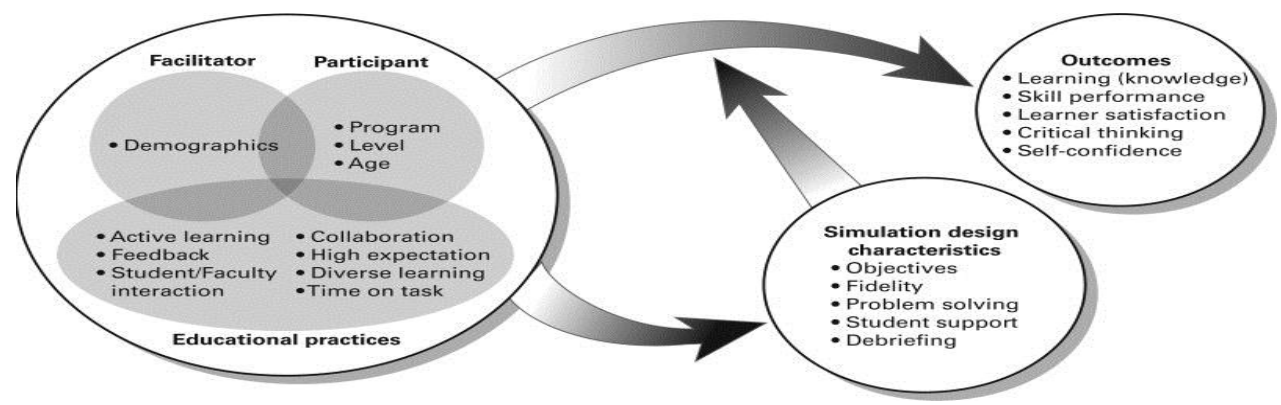

Figure1. Jeffries simulation framework ${ }^{[18]}$

\subsection{Operational Definitions}

Simulation: simulation was defined as a method of training or research that attempts to create a realistic experience in a controlled environment. It is a model that represents a certain phenomenon or activity that allows the learner to acquired knowledge by interacting with the model. ${ }^{[23]}$

Nursing simulation: The definition of simulation was contextualized in nursing education by beginning referred to as method "to replace or 
amplify real patient experience with a scenario designed to replicate real health encounters". ${ }^{23]}$

Achievement: As defined in the Oxford dictionary, a thing done successfully with effort, skill, or courage. ${ }^{[24]}$

Satisfaction: As defined in Oxford dictionary, fulfillment of one's wishes, expectations, or needs, or the pleasure derived from this. ${ }^{[24]}$

\subsection{Aim of the Study}

The current study was conducted to evaluate the effect of simulation on students' achievement in normal labor modules. This aim achieved through (1) Assessing needs of students, (2) Applying simulation modules, (3) Evaluating the effect of simulation modules on students' achievement regarding (stages of labor, mechanism of delivery neonatal outcome and placenta).

\subsection{Research Hypothesis}

The students who learn the labor modules through simulation-based teaching will have significantly higher achievement scores and satisfaction level compared with those who learn through the traditional classroom-based teaching.

\section{SubJeCtS AND METHOdS}

\subsection{Study Design}

A Quasi-experimental study design (Study \& control group) was used.

\subsection{Setting}

The study was conducted at Maternity Nursing laboratory/classroom in the Faculty of Nursing Benha University.

\subsection{Sampling}

A purposive sample composed of 120 students was included. All nursing students', in the $2^{\text {nd }}$ semester of the academic year 2016-2017, enrolled in $3^{\text {rd }}$ year and in the obstetrics \& gynecology department were recruited for this study. A sample of 120 nursing students was divided into equal groups, study, and control group (60 students per each group), applying two clinical teaching methods. Using the traditional method for half of the students (60) as a control group, while using simulation (Noelle mannequin \& videos) for another half of students (60) as a study group.

\subsection{Data Collecting Tool}

The study tools which had been used for data collection was divided into four tools which included the following:

\subsubsection{Tool (I)Structured interview questionnaire sheet}

This tool was designed to assess students' knowledge; it contains three parts: -

\section{- Part one}

It was concerned with the demographic characteristic as name, age, occupation and educational level

\section{- Part two}

It was designed to assess the knowledge of student regarding normal labor. It contains knowledge about, definition of labor, factors affecting labor, difference between true and false labor pain, premonitory sign and symptoms of labor, sure signs of labor, characteristic of uterine contraction and stages of labor. Definition, duration, and diagnosis of every stage of labor $\left(1^{\text {st }}, 2^{\text {nd }}, 3^{\text {rd }}\right)$ were involved. Moreover, students' knowledge regarding the mechanism of delivery, signs of placenta separation, mechanism of placental separation, placenta examination and definition of the fourth stage of labor were entailed in this part.

\section{Scoring system}

Total scoring of the students' knowledge regarding normal labor was equal (20).

1. Adequate knowledge $\geq 75 \%$. (15 to 20 marks)

2. Inadequate knowledge $<75 \%$. (0 to 14 marks)

\section{- $\quad$ Part three}

It was concerned with students' knowledge regarding practical skills of labor stages aim of perineal care, the aim of vaginal examinations, the aim of abdominal examinations, definition, value \& components of the partogram, of the partogram, values of measuring fetal heart rate (FHR) \& signs of fetal distress

\section{Scoring system}

Total scoring of the students' knowledge regarding thepractical skills of labor stages was equal (7).

1. Adequate knowledge $\geq 75 \%$. ( 5 to 7 marks)

2. Inadequate knowledge $<75 \%$. (0 to 4 marks)

\subsubsection{Tool (II) Students practices observational checklist}

It was developed by the researcher to assess students' practices immediately, after and at the end of labor. It contains the procedures that were done for the women such as perineal care, abdominal examination, vaginal examination, handling, assessments of fund us, placental examination and newborn physical assessment. 


\section{Scoring system}

1. Highly satisfactory practice $\geq 85 \%$

2. Satisfactory practice $\quad 75-85 \%$

2.4.3.Tool (III)Media for modules of labor (Noelle mannequin \& Video)

This tools used for training students about simulated videos about labor procedures as perineal care, abdominal examination, vaginal examination, handling, assessments of fund us, placental examination and newborn physical assessment.

\subsubsection{Tool (IV)Students' satisfaction with the learning method(simulation) structured interview questioner}

It was developed to assess students' satisfaction with modules that included, the teaching methods used in this simulation were helpful and effective, the simulation provide student with a variety of learning materials and activities to allow learners to attain knowledge, skills in a safe controlled environment, the teaching materials used in this simulation were motivating student to learn, the method of simulation was suitable to the way of learning, simulation covered critical content necessary for learning, developing the skills and obtaining the required knowledge to perform necessary tasks in a clinical setting, help in understanding the concepts covered in the simulation.

\section{Scoring System}

Total scoring of the students' satisfaction with the learning method was equal (7).
1. Satisfactory $>75 \%$.
(5 to 7 marks)
2. Uncertain $60-75 \%$.
(4 marks)
3. Unsatisfactory $<60 \%$.
(0 to 3 marks)

\subsection{Validity of Tools}

The developed tools were re viewed for content validity by a jury consisting of a group of 5 experts specialized in the obstetric nursing field.

\subsection{Reliability of Tools}

The reliability of the tools was tested using Cronbach's Alpha test.

\subsection{Ethical and Administrative Considerations}

The aim of the study was explained to students before data collection to gain their confidence and trust. An oral consent was obtained from each student to participate in the study they were informed that they could withdraw at any time when they need. The researcher assured maintaining anonymity and confidentiality of each participant. They were assured that the study was not having any physical, social or psychological risk. A written approval was obtained, from the dean of the Faculty of Nursing and head of maternal/newborn health nursing department Benha University, after explaining the purpose of the study and methods of data collection.

\subsection{Pilot Study}

A pilot study was carried out on $10 \%$ of the total sample it included (12 students). It was done to assess the applicability, clarity, and efficiency of the Instruments, estimate the time needed for data collection, and test the feasibility of conducting the study. No modification was done; students who shared in the pilot study were included in the sample.

\subsection{Field Work}

Three phases were adopted to fulfill the aim of the current study as following mentioned; (1): assessment phase, (2): planning phase, (3): implementing phase, (4): evaluation phase. The three phases for data collection took 4 months (from February 1, 2017 to May 31, 2017).

\subsubsection{Assessment and Planning Phase}

The researcher interviewed both study and control groups using tools of data collection (I, II, III, and IV) to determine the students need (pretest), then divide each study and control group students into four equal groups (15 for each). Students in the control group receive the routine of training in the lab (demonstration) by using traditional mannequin and allow them to do re-demonstration (this training phase). While students in the study group received simulated delivery classroom by the researcher using simulated parturient women mannequin (Noelle Simulator) and videos.

\subsubsection{Implementation Phase}

The Program implementation is carried through 7 sessions; 3 for theoretical sessions and 4 for practical ones. The theoretical session about normal labor, including definition, terms, stages, sign \& symptoms and mechanism of labor; sign and symptoms of placental separation, mechanism of placental delivery and care during the $4^{\text {th }}$ stage of labor and each session is 
implemented in 45 min through using learning material as lecture \& group discussion. The practical sessions were concerned with Abdominal examination, vaginal examination, perianal care, assessment of fund us, handling, placental examination, and newborn physical assessment and also each session is implemented in 45 minutes and conducted in the affiliated laboratory of the department including demonstration, videos, and re-demonstration. Implementation phase for each group of study took about two weeks.

\subsubsection{Evaluation Phase}

The researcher started the evaluation phase after the end of re-demonstration for all students in the study and control groups. Each student was evaluated 3 times and the mean score was taken. During this period the researcher observes the students' practice for normal labor through an observational checklist and assessed their knowledge through nursing students' selfadministered questionnaire sheet, the time span of each student's evaluation was 10 minutes at both study and control groups. Comparison between both groups was done using the same tools. Pre-post knowledge tool was utilized to evaluate knowledge. Pre-post-test performance checklist was used to evaluate student practical skills.

Table1. Overview of the elements in the program about simulation modules for nursing students' achievement of normal labor (duration 2 weeks for each group)

\begin{tabular}{|c|c|c|c|c|c|}
\hline Phases & Type & No. & Elements & Objectives & Method \\
\hline $\begin{array}{l}\text { Assessment \& } \\
\text { planning phase }\end{array}$ & \multicolumn{3}{|c|}{ Opening Ceremony } & 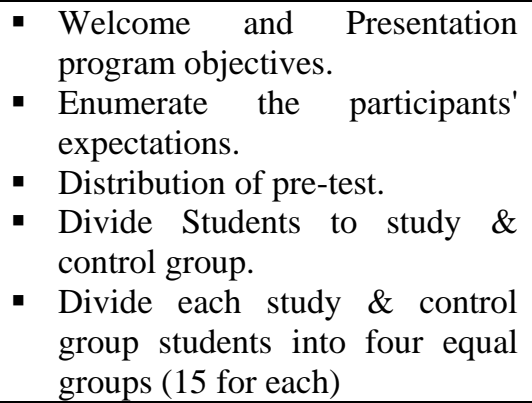 & - Discussion. \\
\hline \multirow[t]{3}{*}{$\begin{array}{c}\text { Implementation } \\
\text { phase }\end{array}$} & \multirow{3}{*}{ 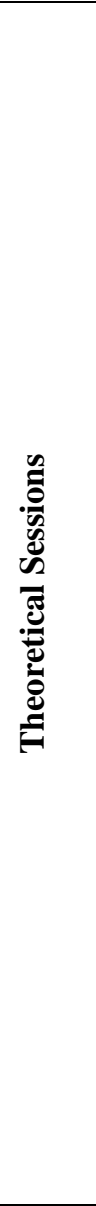 } & 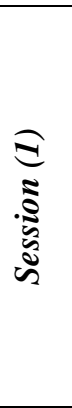 & $\begin{array}{l}\text { knowledge } \\
\text { regarding the } \\
\text { physiology of } \\
\text { normal labor }\end{array}$ & $\begin{array}{l}\text { - Define normal labor } \\
\text { - List factors affecting labor } \\
\text { - Differentiate between true and } \\
\text { false labor pain } \\
\text { - List premonitory Symptoms and } \\
\text { Signs of Labor } \\
\text { - Describe sure signs of labor } \\
\text { - Explain the characteristic of } \\
\text { uterine contraction } \\
\text { - Mention stages of normal labor }\end{array}$ & $\begin{array}{l}\text { - Power point } \\
\text { - Video }\end{array}$ \\
\hline & & 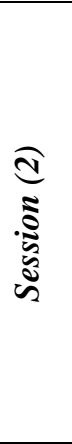 & $\begin{array}{l}\text { knowledge } \\
\text { regarding the } \\
\text { first \& the } \\
\text { second stage } \\
\text { of labor }\end{array}$ & 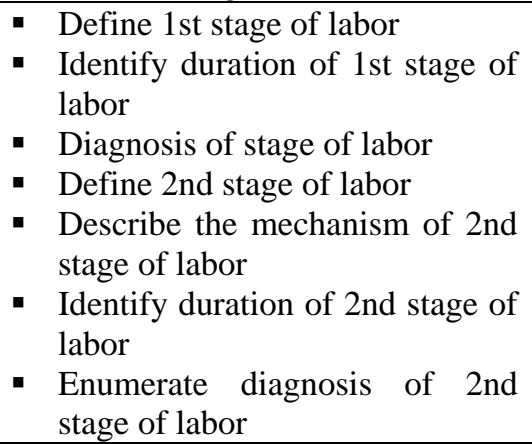 & $\begin{array}{l}\text { - Power point } \\
\text { - Video }\end{array}$ \\
\hline & & 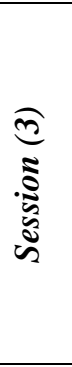 & $\begin{array}{l}\text { knowledge } \\
\text { regarding the } \\
\text { third \& fourth } \\
\text { stage of labor }\end{array}$ & 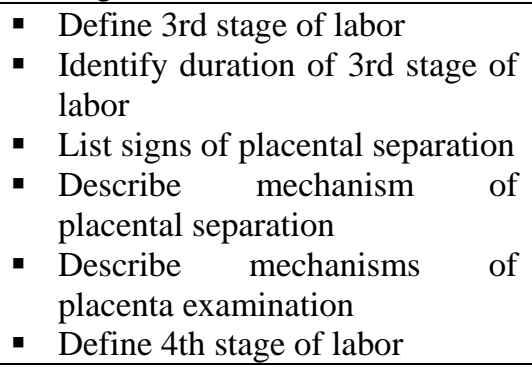 & $\begin{array}{ll}\text { - } & \text { Power point } \\
\text { - Video }\end{array}$ \\
\hline
\end{tabular}


Call for Activation of Simulation Modules for Nursing Students' Achievement and Satisfaction of Normal Labor: A Quasi-Experimental Study

\begin{tabular}{|c|c|c|c|c|c|}
\hline & \multirow{4}{*}{ 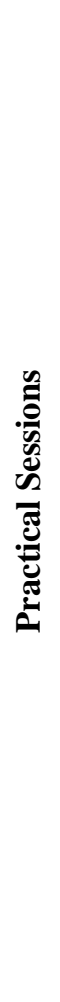 } & 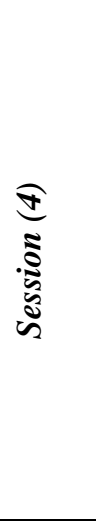 & $\begin{array}{l}\text { Knowledge } \\
\text { regarding } \\
\text { practical skills } \\
\text { of labor stages }\end{array}$ & 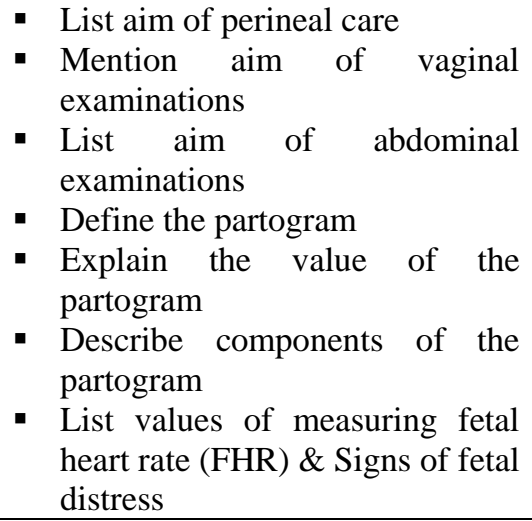 & - Power point \\
\hline & & 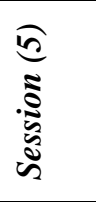 & \multirow[t]{3}{*}{$\begin{array}{l}\text { Practices } \\
\text { regarding } \\
\text { labor } \\
\text { procedures }\end{array}$} & $\begin{array}{l}\text { Demonstrate } \\
\text { examinations } \\
\text { - } \begin{array}{l}\text { Practice assessment of fundus } \\
\text { level }\end{array} \\
\text { - Apply perineal care }\end{array}$ & $\begin{array}{l}\text { - Noelle } \\
\text { Simulator } \\
\text { - Videos }\end{array}$ \\
\hline & & 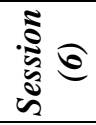 & & $\begin{array}{lll}\text { - } & \text { Demonstrate } & \text { vaginal } \\
\text { examinations } & \\
\text { - } & \text { Practice handling } & \\
\end{array}$ & $\begin{array}{ll}\text { - } & \text { Noelle } \\
& \text { Simulator } \\
\text { - } & \text { Videos } \\
\end{array}$ \\
\hline & & 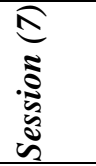 & & 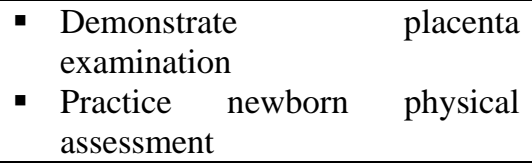 & $\begin{array}{ll}\text { - } & \text { Noelle } \\
\text { Simulator } \\
\text { - Videos }\end{array}$ \\
\hline $\begin{array}{c}\text { Evaluation } \\
\text { phase }\end{array}$ & \multicolumn{3}{|c|}{ Closing } & 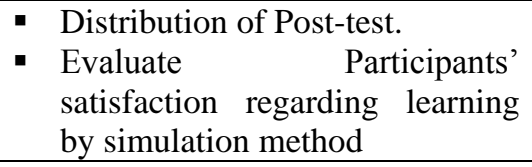 & $\begin{array}{l}\text { - } \text { Check-list } \\
\text { - Thanks to all } \\
\text { participants. }\end{array}$ \\
\hline
\end{tabular}

\subsection{Statistical design}

Data analysis was performed using IBM SPSS statistical software version 22. Mean and standard deviation were done for quantitative data frequency distribution was done; ( $t$ ) test was used for qualitative data $\left(\mathrm{X}^{2}\right)$. A correlation coefficient ( $\Gamma$ ) was used to evaluate the relationship between the study variable. A statistical significant difference was considered if $\mathrm{p}$-value $\leq 0.05$ and a highly statistical significance was considered when $\mathrm{p}$-value $\leq$ 0.001 .

\section{Results}

Table (2): shows that, participant students with a mean age of $21.43 \pm 1.98$ and $21.04 \pm 1.46$ for study and control group, respectively. More than half $(53.3 \% \& 56.7 \%)$ as well as most $(71.7 \%$ \& $70.0 \%)$ of the study and control group, respectively, had technical health institute/nursing institute and were from rural areas, respectively. No statistical difference among students of study and control groups regarding their personal characteristics $(\mathrm{p}>$ $0.05)$.

Table2. Distribution of studied sample regarding personal characteristics $(N=120)$

\begin{tabular}{|c|c|c|c|c|c|c|}
\hline \multirow[t]{2}{*}{ Personnel characteristics } & \multicolumn{2}{|c|}{ Study $\operatorname{group}(\mathrm{N}=60)$} & \multicolumn{2}{|c|}{ Control group $(\mathrm{N}=60)$} & \multirow{2}{*}{$\begin{array}{c}\text { Chi-square } \\
\text { Test }\left(x^{2}\right)\end{array}$} & \multirow[t]{2}{*}{$P$ value } \\
\hline & No & $\%$ & No & $\%$ & & \\
\hline \multicolumn{7}{|l|}{ Age in (years) } \\
\hline $20-21$ & 26 & $43.3 \%$ & 32 & $53.3 \%$ & \multirow[t]{3}{*}{1.20} & \multirow[t]{3}{*}{$>0.05$} \\
\hline $22-23$ & 34 & $56.7 \%$ & 28 & $46.7 \%$ & & \\
\hline Mean \pm SD & \multicolumn{2}{|c|}{$(21.43 \pm 1.98)$} & \multicolumn{2}{|c|}{$(21.04 \pm 1.46)$} & & \\
\hline \multicolumn{7}{|l|}{ Educational level } \\
\hline Secondary school & 28 & $46.7 \%$ & 26 & $43.3 \%$ & \multirow[t]{2}{*}{0.135} & \multirow[t]{2}{*}{$>0.05$} \\
\hline $\begin{array}{l}\text { Technical health institute \& } \\
\text { nursing institute }\end{array}$ & 32 & $53.3 \%$ & 34 & $56.7 \%$ & & \\
\hline \multicolumn{7}{|l|}{ Residence } \\
\hline Rural & 43 & $71.7 \%$ & 42 & $70.0 \%$ & \multirow[t]{2}{*}{0.040} & \multirow[t]{2}{*}{$>0.05$} \\
\hline Urban & 17 & $28.3 \%$ & 18 & $30.0 \%$ & & \\
\hline
\end{tabular}

NS: $p>0.05 . * p$ value is considered significant 
Call for Activation of Simulation Modules for Nursing Students' Achievement and Satisfaction of Normal Labor: A Quasi-Experimental Study

Table (3): indicates no statistical significant differences between study and control group regarding their theoretical knowledge (preintervention) about definition of normal labor, differences between true and false labor pain, premonitory symptoms and signs of labor, sure signs of labor, characteristics of uterine contraction knowledge about stages of normal labor, mechanisms of different stages of labor, signs of placenta separation and mechanisms of placental separation $(p>0.05)$. Otherwise, a highly statistical significant difference between study and control groups, regarding their knowledge about previously mentioned items post-intervention compared to pre-intervention, was observed $(\mathrm{p}<0.001)$.

Table3. Distribution of studied sample according their pre/post-intervention theoretical knowledge about labor $(N=120)$

\begin{tabular}{|c|c|c|c|c|c|c|c|c|c|c|c|c|c|c|c|c|c|c|c|c|}
\hline \multirow[t]{4}{*}{ Item } & \multicolumn{8}{|c|}{ pre-intervention } & \multirow[t]{4}{*}{$x^{2}$} & \multirow{4}{*}{$\begin{array}{c}\mathbf{P} \\
\text { value }\end{array}$} & \multicolumn{8}{|c|}{ post-intervention } & \multirow[t]{4}{*}{$x^{2}$} & \multirow[t]{4}{*}{$P$ value } \\
\hline & \multicolumn{4}{|c|}{ Study group } & \multicolumn{4}{|c|}{ Control group } & & & & Study & grol & & & Control & I gro & up & & \\
\hline & \multicolumn{2}{|c|}{ Incorrect } & \multicolumn{2}{|c|}{ Correct } & \multicolumn{2}{|c|}{ Incorrect } & \multicolumn{2}{|c|}{ Correct } & & & \multicolumn{2}{|c|}{ Incorrect } & \multicolumn{2}{|c|}{ Correct } & \multicolumn{2}{|c|}{ Incorrect } & \multicolumn{2}{|c|}{ Correct } & & \\
\hline & No & $\%$ & No & $\%$ & No & $\%$ & No & $\%$ & & & No & $\%$ & No & $\%$ & No & $\%$ & No & $\%$ & & \\
\hline $\begin{array}{l}\text { Definition of } \\
\text { normal labor }\end{array}$ & 54 & 90.0 & 6 & 10.0 & 49 & 81.7 & 11 & 18.3 & 1.71 & $>0.05$ & 14 & 23.3 & 47 & 78.3 & 46 & 76.7 & 13 & 21.7 & 36.31 & $<0.001 * *$ \\
\hline $\begin{array}{c}\text { Factors } \\
\text { affecting labor }\end{array}$ & 45 & 75.0 & 15 & 25.0 & 41 & 68.3 & 19 & 31.7 & 0.657 & $>0.05$ & 24 & 40.0 & 37 & 61.7 & 36 & 60.0 & 23 & 38.3 & 5.63 & $<0.05^{*}$ \\
\hline $\begin{array}{c}\text { Differences } \\
\text { between True } \\
\text { and False Labor } \\
\text { Pain }\end{array}$ & 50 & 83.3 & 10 & 16.7 & 53 & 88.3 & 7 & 11.7 & 0.617 & $>0.05$ & 7 & 11.7 & 53 & 88.3 & 53 & 88.3 & 7 & 11.7 & 70.53 & $<0.001 * *$ \\
\hline $\begin{array}{c}\text { Premonitory } \\
\text { Symptoms and } \\
\text { Signs of Labor }\end{array}$ & 47 & 78.3 & 13 & 21.7 & 52 & 86.7 & 8 & 13.3 & 1.44 & $>0.05$ & 10 & 16.7 & 50 & 83.3 & 50 & 83.3 & 10 & 16.7 & 53.33 & $<0.001 * *$ \\
\hline $\begin{array}{c}\text { Sure signs of } \\
\text { labor }\end{array}$ & 43 & 71.7 & 17 & 28.3 & 45 & 75.0 & 15 & 25.0 & 0.170 & $>0.05$ & 14 & 23.3 & 45 & 75.0 & 46 & 76.7 & 15 & 25.0 & 32.04 & $<0.001 * *$ \\
\hline $\begin{array}{c}\text { Characteristic } \\
\text { of uterine } \\
\text { contraction }\end{array}$ & 52 & 86.7 & 8 & 13.3 & 55 & 91.7 & 5 & 8.3 & 0.776 & $>0.05$ & 5 & 8.3 & 55 & 91.7 & 55 & 91.7 & 5 & 8.3 & 83.33 & $<0.001 * *$ \\
\hline $\begin{array}{c}\text { Stages of } \\
\text { normal labor }\end{array}$ & 54 & 90.0 & 6 & 10.0 & 57 & 95.0 & 3 & 5.0 & 1.08 & $>0.05$ & 4 & 6.7 & 56 & 93.3 & 56 & 93.3 & 4 & 6.7 & 90.13 & $<0.001 * *$ \\
\hline $\begin{array}{c}\text { Definition of } \\
1^{\text {st }} \text { stage of labor }\end{array}$ & 53 & 88.3 & 7 & 11.7 & 55 & 91.7 & 5 & 8.3 & 0.370 & $>0.05$ & 7 & 11.7 & 53 & 88.3 & 53 & 88.3 & 7 & 11.7 & 70.53 & $<0.001 * *$ \\
\hline $\begin{array}{l}\text { Duration of } 1^{\text {st }} \\
\text { stage of labor }\end{array}$ & 55 & 91.7 & 5 & 8.3 & 56 & 93.3 & 4 & 6.7 & 0.120 & $>0.05$ & 0 & 0.0 & 60 & 100.0 & 44 & 73.3 & 16 & 26.7 & 69.47 & $<0.001 * *$ \\
\hline $\begin{array}{c}\text { Diagnosis of } 1^{\text {st }} \\
\text { stage of labor }\end{array}$ & 45 & 75.0 & 15 & 25.0 & 40 & 66.7 & 20 & $33.3 \%$ & 1.00 & $>0.05$ & 2 & 3.3 & 38 & 63.3 & 58 & 96.7 & 22 & 36.7 & 48.60 & $<0.001 * *$ \\
\hline $\begin{array}{c}\text { Definition of } \\
2^{\text {nd }} \text { stage of } \\
\text { labor }\end{array}$ & 46 & 76.7 & 14 & 23.3 & 44 & 73.3 & 16 & 26.7 & 0.178 & $>0.05$ & 11 & 18.3 & 49 & 81.7 & 39 & 65.0 & 21 & 35.0 & 26.88 & $<0.001 * *$ \\
\hline $\begin{array}{l}\text { Mechanism of } \\
2^{\text {nd }} \text { stage of } \\
\text { labor }\end{array}$ & 37 & 61.7 & 23 & 38.3 & 36 & 60.0 & 24 & 40.0 & 0.035 & $>0.05$ & 8 & 13.3 & 52 & 86.7 & 30 & 50.0 & 30 & 50.0 & 18.63 & $<0.001 * *$ \\
\hline $\begin{array}{l}\begin{array}{c}\text { Duration of } \\
2^{\text {nd }} \text { stage of } \\
\text { labor }\end{array} \\
\text { labor }\end{array}$ & 47 & 78.3 & 13 & 21.7 & 45 & 75.0 & 15 & 25.0 & 0.186 & $>0.05$ & 4 & 6.7 & 56 & 93.3 & 41 & 68.3 & 19 & 31.7 & 48.67 & $<0.001 * *$ \\
\hline $\begin{array}{c}\text { Diagnosis of } 2^{\text {nd }} \\
\text { stage of labor }\end{array}$ & 52 & 86.7 & 8 & 13.3 & 51 & 85.0 & 9 & $15.0 \%$ & 0.069 & $>0.05$ & 0 & 0.0 & 38 & 63.3 & 60 & 100.0 & 22 & 36.7 & 55.61 & $<0.001 * *$ \\
\hline $\begin{array}{c}\text { Definition of } \\
3^{\text {rd }} \text { stage of labor }\end{array}$ & 45 & 75.0 & 15 & 25.0 & 42 & 70.0 & 18 & 30.0 & 0.376 & $>0.05$ & 7 & 11.7 & 53 & 88.3 & 35 & 58.3 & 25 & 41.7 & 28.71 & $<0.001 * *$ \\
\hline $\begin{array}{c}\text { Duration of } \\
3^{\text {rd }} \text { stage of labor }\end{array}$ & 43 & 71.7 & 17 & 28.3 & 41 & 68.3 & 19 & 31.7 & 0.159 & $>0.05$ & 10 & 16.7 & 50 & 83.3 & 38 & 63.3 & 22 & 36.7 & 27.22 & $<0.001 * *$ \\
\hline $\begin{array}{c}\text { Signs of } \\
\text { placental } \\
\text { separation }\end{array}$ & 54 & 90.0 & 6 & 10.0 & 52 & 86.7 & 8 & 13.3 & 0.323 & $>0.05$ & 2 & 3.3 & 58 & 96.7 & 50 & 83.3 & 10 & 16.7 & 78.19 & $<0.001 * *$ \\
\hline $\begin{array}{c}\text { Mechanism of } \\
\text { placental } \\
\text { separation } \\
\end{array}$ & 52 & 86.7 & 8 & 13.3 & 46 & 76.7 & 14 & 23.3 & 2.00 & $>0.05$ & 3 & 5.0 & 57 & 95.0 & 42 & 70.0 & 18 & 30.0 & 54.08 & $<0.001 * *$ \\
\hline $\begin{array}{c}\text { Mechanisms of } \\
\text { placenta } \\
\text { examination }\end{array}$ & 42 & 70.0 & 18 & 30.0 & 46 & 76.7 & 14 & 23.3 & 0.682 & $>0.05$ & 5 & 8.3 & 55 & 91.7 & 44 & 73.3 & 16 & 26.7 & 52.46 & $<0.001 * *$ \\
\hline $\begin{array}{c}\text { Definition of } 4^{\text {th }} \\
\text { stage of labor }\end{array}$ & 55 & 91.7 & 5 & 8.3 & 56 & 93.3 & 4 & 6.7 & 0.120 & $>0.05$ & 0 & 0.0 & 60 & 100.0 & 44 & 73.3 & 16 & 26.7 & 69.47 & $<0.001 * *$ \\
\hline
\end{tabular}

NS: $p>0.05 . \quad * p$ value is considered significant

Table (4): reveals no statistical significant differences, between study and control groups

ARC Journal of Nursing and Healthcare **p value is considered highly significant

regarding their theoretical knowledge in preintervention phase compared to highly 
Call for Activation of Simulation Modules for Nursing Students' Achievement and Satisfaction of Normal Labor: A Quasi-Experimental Study

statistically significant difference in postintervention phase, about practical skills of labor including aim of perineal care, vaginal examination, and abdominal examination, definition of partogram, value of partogram and signs of fetal stress.

Table4. Distribution of studied sample according their pre/post-intervention theoretical knowledge about practical skills of labor stages $(N=120)$

\begin{tabular}{|c|c|c|c|c|c|c|c|c|c|c|c|c|c|c|c|c|c|c|c|c|}
\hline \multirow[t]{4}{*}{ Item } & \multicolumn{8}{|c|}{ pre-intervention } & \multirow[t]{4}{*}{$x^{2}$} & \multirow{4}{*}{$\begin{array}{c}\mathbf{P} \\
\text { value }\end{array}$} & \multicolumn{8}{|c|}{ post-intervention } & \multirow[t]{4}{*}{$x^{2}$} & \multirow{4}{*}{$\begin{array}{c}P \\
\text { value }\end{array}$} \\
\hline & \multicolumn{4}{|c|}{ Study group } & \multicolumn{4}{|c|}{ Control group } & & & \multicolumn{4}{|c|}{\begin{tabular}{|l|} 
Study group \\
\end{tabular}} & \multicolumn{4}{|c|}{ Control group } & & \\
\hline & \multicolumn{2}{|c|}{ Incorrect } & \multicolumn{2}{|c|}{ Correct } & \multicolumn{2}{|c|}{ Incorrect } & \multicolumn{2}{|c|}{ Correct } & & & \multicolumn{2}{|c|}{ Incorrect } & \multicolumn{2}{|c|}{ Correct } & \multicolumn{2}{|c|}{ Incorrect } & \multicolumn{2}{|c|}{ Correct } & & \\
\hline & No & $\%$ & No & $\%$ & No & $\%$ & No & $\%$ & & & No & $\%$ & No & $\%$ & No & $\%$ & No & $\%$ & & \\
\hline Aim of perineal care & 52 & 86.7 & 8 & 13.3 & 51 & 85.0 & 9 & $15.0 \%$ & 0.069 & $>0.05$ & 0 & 0.0 & 38 & 63.3 & 60 & 100.0 & 22 & 36.7 & 55.61 & $\begin{array}{c}< \\
0.001 \\
* *\end{array}$ \\
\hline $\begin{array}{l}\text { Aim of vaginal } \\
\text { examinations }\end{array}$ & 43 & 71.7 & 17 & 28.3 & 45 & 75.0 & 15 & $25.0 \%$ & 0.170 & $>0.05$ & 7 & 11.7 & 43 & 71.7 & 53 & 88.3 & 17 & 28.3 & 44.43 & $\begin{array}{c}< \\
0.001 \\
* *\end{array}$ \\
\hline $\begin{array}{l}\text { Aim of abdominal } \\
\text { examinations }\end{array}$ & 43 & 71.7 & 17 & 28.3 & 42 & 70.0 & 18 & $30.0 \%$ & 0.040 & $>0.05$ & 12 & 20.0 & 34 & 56.7 & 48 & 80.0 & 26 & 43.3 & 17.06 & $\begin{array}{c}< \\
0.001 \\
* *\end{array}$ \\
\hline $\begin{array}{c}\text { Definition of the } \\
\text { partogram }\end{array}$ & 49 & 81.7 & 11 & 18.3 & 45 & 75.0 & 15 & $25.0 \%$ & 0.786 & $>0.05$ & 2 & 3.3 & 42 & 70.0 & 58 & 96.7 & 18 & 30.0 & 57.41 & $\begin{array}{c}< \\
0.001 \\
* *\end{array}$ \\
\hline $\begin{array}{l}\text { Value of the } \\
\text { partogram }\end{array}$ & 45 & 75.0 & 15 & 25.0 & 40 & 66.7 & 20 & $33.3 \%$ & 1.00 & $>0.05$ & 2 & 3.3 & 38 & 63.3 & 58 & 96.7 & 22 & 36.7 & 48.60 & $\begin{array}{c}< \\
0.001 \\
* *\end{array}$ \\
\hline $\begin{array}{c}\text { Components of the } \\
\text { partogram }\end{array}$ & 43 & 71.7 & \begin{tabular}{|l|}
17 \\
\end{tabular} & 28.3 & 40 & 66.7 & 20 & $33.3 \%$ & 0.352 & $>0.05$ & 5 & 8.3 & 35 & 58.3 & 55 & 91.7 & 25 & \begin{tabular}{|l|}
41.7 \\
\end{tabular} & 33.75 & $\begin{array}{c}< \\
0.001 \\
* *\end{array}$ \\
\hline $\begin{array}{c}\text { Values of measuring } \\
\text { fetal heart rate (FHR) } \\
\text { \&Signs of fetal } \\
\text { distress }\end{array}$ & 44 & 73.3 & 16 & 26.7 & 46 & 76.7 & 14 & $23.3 \%$ & \begin{tabular}{|l|}
0.178 \\
\end{tabular} & $>0.05$ & 0 & 0.0 & 45 & 75.0 & 60 & 100.0 & 15 & 25.0 & 72.00 & $\begin{array}{c}< \\
0.001 \\
* *\end{array}$ \\
\hline
\end{tabular}

NS: $p>0.05 . * p$ value is considered significant. **p value is considered highly significant

Figure2: portrays ahigh progression of total adequate knowledge of the study group after intervention phases, associated with high regression of inadequate one, compared to the control group.

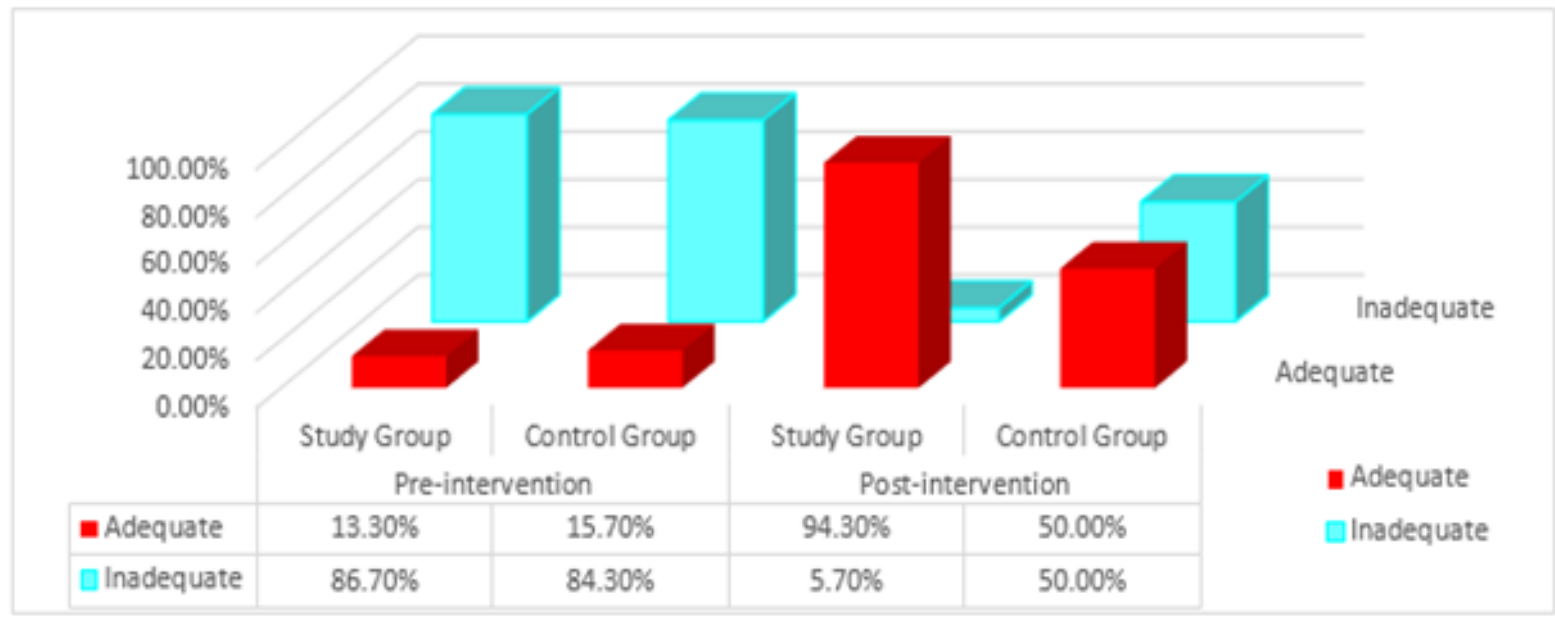

Figure2. Percentage distribution of studied sample regarding their total knowledge at pre \& post intervention $(N=120)$

Table (5): reveals a highly statistically differences regarding practical skills during the process of labor including perineal care, abdominal examination, vaginal examination, handling, assessment of fund us, placental examination and newborn physical assessment immediately at the re-demonstration phase (in the $1^{\text {st }}$ evaluation). While a highly statistically significant difference regarding the same skills during the process of labor at clinical area evaluation phase (in the $2^{\text {nd }}$ evaluation). 
Call for Activation of Simulation Modules for Nursing Students' Achievement and Satisfaction of Normal Labor: A Quasi-Experimental Study

Table5. Distribution of mean score of studied sample practice regarding labor procedures immediately $\left(1^{\text {st }}\right.$ trial) at the re demonstration phase $)$ and $\left(2^{\text {nd }}\right.$ trial $)$ at the clinical area evaluation phase $(N=120)$

\begin{tabular}{|c|c|c|c|c|c|c|c|c|c|}
\hline \multirow[t]{3}{*}{ Procedure } & \multirow[t]{3}{*}{ score } & \multicolumn{2}{|c|}{ First Trial } & \multirow{3}{*}{$\begin{array}{c}\text { Indepe } \\
\text { ndent } \\
\text { t test }\end{array}$} & \multirow{3}{*}{$\begin{array}{c}\mathbf{P} \\
\text { value }\end{array}$} & \multicolumn{2}{|c|}{ Second Trial } & \multirow{3}{*}{$\begin{array}{l}\text { Indepe } \\
\text { ndent t } \\
\text { test }\end{array}$} & \multirow{3}{*}{$\begin{array}{c}\mathbf{P} \\
\text { value }\end{array}$} \\
\hline & & $\begin{array}{l}\text { Study } \\
\text { group }\end{array}$ & $\begin{array}{l}\text { Control } \\
\text { group }\end{array}$ & & & $\begin{array}{l}\text { Study } \\
\text { group }\end{array}$ & $\begin{array}{l}\text { Control } \\
\text { group }\end{array}$ & & \\
\hline & & $\begin{array}{l}\text { Mean } \pm \\
\text { SD }\end{array}$ & $\begin{array}{l}\text { Mean } \pm \\
\text { SD }\end{array}$ & & & $\begin{array}{l}\text { Mean } \\
\pm \text { SD }\end{array}$ & $\begin{array}{c}\text { Mean } \\
\pm \text { SD }\end{array}$ & & \\
\hline Perineal care & 27 & $\begin{array}{c}25.1200 \pm \\
.57159\end{array}$ & $\begin{array}{c}24.0417 \pm \\
1.20483\end{array}$ & 6.26 & $\begin{array}{c}< \\
0.001 * *\end{array}$ & $\begin{array}{c}25.1933 \pm \\
.55810\end{array}$ & $\begin{array}{c}24.3833 \pm \\
1.25336\end{array}$ & 4.57 & $\begin{array}{c}< \\
0.001 * *\end{array}$ \\
\hline $\begin{array}{c}\text { Abdominal } \\
\text { examinations }\end{array}$ & 15 & $\begin{array}{c}13.4478 \pm \\
2.12201\end{array}$ & $\begin{array}{c}12.5733 \pm \\
0.71376\end{array}$ & 3.02 & $\begin{array}{c}< \\
0.001 * *\end{array}$ & $\begin{array}{c}13.5328 \pm \\
2.1138\end{array}$ & $\begin{array}{c}12.9300 \pm \\
0.63999\end{array}$ & 2.11 & $<0.05^{*}$ \\
\hline $\begin{array}{c}\text { Vaginal } \\
\text { examinations }\end{array}$ & 30 & $\begin{array}{c}28.2350 \pm \\
1.85059\end{array}$ & $\begin{array}{c}27.6167 \pm \\
1.07501\end{array}$ & 2.23 & $\begin{array}{c}<< \\
0.001 * *\end{array}$ & $\begin{array}{c}28.5683 \pm \\
1.0852\end{array}$ & $\begin{array}{c}27.8750 \pm \\
0.79525\end{array}$ & 3.99 & $\begin{array}{c}< \\
0.001 * *\end{array}$ \\
\hline Handling & 20 & $\begin{array}{c}17.9850 \pm \\
0.65686\end{array}$ & $\begin{array}{c}17.4250 \pm \\
0.72384\end{array}$ & 4.43 & $\begin{array}{c}< \\
0.001 * *\end{array}$ & $\begin{array}{c}18.2383 \pm \\
0.49235\end{array}$ & $\begin{array}{c}17.5667 \pm \\
0.75052\end{array}$ & 5.79 & $\begin{array}{c}< \\
0.001 * *\end{array}$ \\
\hline $\begin{array}{l}\text { Assessment } \\
\text { of fundus }\end{array}$ & 25 & $\begin{array}{c}23.4850 \pm \\
0.61142\end{array}$ & $\begin{array}{c}22.3333 \pm \\
0.62887\end{array}$ & 10.17 & $\begin{array}{c}< \\
0.001 * *\end{array}$ & $\begin{array}{c}23.6000 \pm \\
0.53362\end{array}$ & $\begin{array}{c}22.4583 \pm \\
0.71481\end{array}$ & 9.91 & $\begin{array}{c}< \\
0.001 * *\end{array}$ \\
\hline $\begin{array}{c}\text { Placenta } \\
\text { examination }\end{array}$ & 16 & $\begin{array}{c}14.5667 \pm \\
.94091\end{array}$ & $\begin{array}{c}13.6250 \pm \\
0.93711\end{array}$ & 5.49 & $\begin{array}{c}< \\
0.001 * *\end{array}$ & $\begin{array}{c}14.8417 \pm \\
0.722\end{array}$ & $\begin{array}{c}13.8250 \pm \\
0.90584\end{array}$ & 6.77 & $\begin{array}{c}< \\
0.001 * *\end{array}$ \\
\hline $\begin{array}{c}\text { Newborn } \\
\text { physical } \\
\text { assessment }\end{array}$ & 20 & $\begin{array}{c}18.6667 \pm \\
0.42850\end{array}$ & $\begin{array}{c}17.4917 \pm \\
0.96766\end{array}$ & 8.60 & $\begin{array}{c}<< \\
0.001 * *\end{array}$ & $\begin{array}{c}18.7833 \pm \\
.28174\end{array}$ & $\begin{array}{c}17.7583 \pm \\
0.60008\end{array}$ & 11.97 & $\begin{array}{c}< \\
0.001 * *\end{array}$ \\
\hline
\end{tabular}

NS: $p>0.05$. *p value is considered significant $* * p$ value is considered highly significant

Table (6): reveals a highly statistically significant difference regarding students' practical skills during the process of labor including perineal care, abdominal examination, vaginal examination, handling, assessment of fund us, placental examination and newborn physical assessment of both phases of the assessment.

Table6. Distribution of mean score of studied sample regarding average practice score about labor procedures of both phases of assessment $(N=120)$

\begin{tabular}{|c|c|c|c|c|}
\hline \multirow[t]{3}{*}{ Procedure } & \multicolumn{2}{|c|}{ Average score of the two different trials } & \multirow{3}{*}{$\begin{array}{c}\text { Independent } \\
\text { t test }\end{array}$} & \multirow[t]{3}{*}{ P value } \\
\hline & Study group $(N=60)$ & Control group $(\mathrm{N}=60)$ & & \\
\hline & Mean \pm SD & Mean \pm SD & & \\
\hline Perineal care & $25.1567 \pm 0.54907$ & $24.2125 \pm 1.17154$ & 5.85 & $<0.001 * *$ \\
\hline Abdominal examinations & $13.4903 \pm 2.11541$ & $12.7517 \pm 0.58149$ & 2.60 & $<0.001 * *$ \\
\hline Vaginal examinations & $28.4017 \pm 1.31204$ & $27.7458 \pm 0.87272$ & 3.22 & $<0.001 * *$ \\
\hline Handling & $18.1117 \pm 0.50727$ & $17.4958 \pm 0.70934$ & 5.47 & $<0.001 * *$ \\
\hline Assessment of fundus & $23.5425 \pm 0.55722$ & $22.3958 \pm 0.63495$ & 10.51 & $<0.001 * *$ \\
\hline Placenta examination & $14.7042 \pm 0.75981$ & $13.7250 \pm 0.87781$ & 6.53 & $<0.001 * *$ \\
\hline $\begin{array}{c}\text { Newborn physical } \\
\text { assessment }\end{array}$ & $18.7250 \pm 0.33096$ & $17.6250 \pm 0.73430$ & 10.57 & $<0.001 * *$ \\
\hline Total practice sore & $142.1320 \pm 3.52868$ & $135.9517 \pm 2.40333$ & 11.21 & $<0.001 * *$ \\
\hline
\end{tabular}

NS: $p>0.05$. *p value is considered significant. **p value is considered highly significant

Table (7): indicates a highly statistically significant difference between study and control group regarding their total practical skills of stages of labor at pre/post-intervention phases.

Table7. Distribution of studied sample regarding pre \&post intervention practical skills of stages of labor $(N=120)$

\begin{tabular}{|c|c|c|c|c|c|c|c|c|c|c|}
\hline \multirow{3}{*}{$\begin{array}{c}\text { Time of } \\
\text { evaluation }\end{array}$} & \multicolumn{4}{|c|}{ Study group $(\mathbf{N}=60)$} & \multicolumn{4}{|c|}{ Control group $(\mathrm{N}=60)$} & \multirow{3}{*}{$\begin{array}{c}\text { Chi-square } \\
\text { Test }\left(\boldsymbol{x}^{2}\right)\end{array}$} & \multirow[t]{3}{*}{$P$ value } \\
\hline & \multicolumn{2}{|c|}{ Adequate } & \multicolumn{2}{|c|}{ Inadequate } & \multicolumn{2}{|c|}{ Adequate } & \multicolumn{2}{|c|}{ Inadequate } & & \\
\hline & No & $\%$ & No & $\%$ & No & $\%$ & No & $\%$ & & \\
\hline Pre-intervention & 8 & 13.3 & 52 & 86.7 & 10 & 16.7 & 50 & 83.3 & 0.796 & $>0.05$ \\
\hline $\begin{array}{c}\text { Post- } \\
\text { intervention }\end{array}$ & 56 & 93.3 & 4 & 6.7 & 30 & 50.0 & 30 & 50.0 & 27.74 & $<0.001 * *$ \\
\hline
\end{tabular}

NS: $\mathrm{p}>0.05 . * p$ value is considered significant $* * p$ value is considered highly significant 
Table (8): illustrated students' satisfaction with learning by simulation modules. It shows that $78.3 \%$ of the studied sample agrees that "simulation provides students with a variety of learning materials and activities to promote the learning curriculum", $73.3 \%$ agree that "the

Table8. Distribution of studied sample regarding satisfaction score about simulation method $(N=60)$

\begin{tabular}{|l|l|l|l|l|l|l|}
\hline \multicolumn{1}{|c|}{ Satisfaction } & \multicolumn{2}{|c|}{ Agree } & \multicolumn{2}{c|}{ Uncertain } & \multicolumn{2}{c|}{ Disagree } \\
\cline { 4 - 8 } & No & $\mathbf{\%}$ & No & $\mathbf{\%}$ & No & $\mathbf{\%}$ \\
\hline $\begin{array}{l}\text { 1. The teaching methods used in this simulation were helpful and } \\
\text { effective }\end{array}$ & 44 & 73.3 & 12 & 20.0 & 4 & 6.7 \\
\hline $\begin{array}{l}\text { 2. The simulation provides student with a variety of learning materials } \\
\text { and activities to promote the learning curriculum }\end{array}$ & 47 & 78.3 & 9 & 15.0 & 4 & 6.7 \\
\hline $\begin{array}{l}\text { 3. The teaching materials used in this simulation were motivating } \\
\text { student to learn. }\end{array}$ & 36 & 60.0 & 22 & 36.7 & 2 & 3.3 \\
\hline 4. The method of simulation was suitable to the way of learning & 39 & 65.0 & 16 & 26.7 & 5 & 8.3 \\
\hline 5. Simulation covered critical content necessary for learning. & 41 & 68.3 & 15 & 25.0 & 4 & 6.7 \\
\hline $\begin{array}{l}\text { 6. developing the skills and obtaining the required knowledge to } \\
\text { perform necessary tasks in a clinical setting }\end{array}$ & 41 & 68.3 & 13 & 21.7 & 6 & 10.0 \\
\hline 7. Help in understanding the concepts covered in the simulation. & 39 & 65.0 & 19 & 31.7 & 2 & 3.3 \\
\hline
\end{tabular}

\section{DISCUSSION}

Traditional pedagogical techniques are still very much the norm for higher education. Student learning remains largely based upon extracting knowledge from texts and lectures. This style of teaching rarely gives students the opportunity to apply their newfound knowledge to actual situations, resulting in a serious time lag between students learning and applying new knowledge. So, it attributed to simulations relates to the suggested improvements in overall student learning. For much of the literature has stressed the increased levels of cognitive learning, it has the power to recreate complex, dynamic political Processes in the lecture, allowing students to examine the motivations, behavioral Constraints, resources and interactions among institutional actors. ${ }^{[25]}$

Nowadays simulation is taking an important place in training and education of healthcare professionals. Simulations have been shown to be an effective tool in traditional learning environments. Innovative advances in technology have introduced a variety of tools to enhance learning in higher education. Among these, simulations have been used to support a variety of cognitive learning styles, to facilitate higher-order thinking and problem-solving skills, and to augment differential, collaborative, and mastery learning. ${ }^{[26,27]}$ Several factors drive the increase of using simulation in nursing and health professional education. Inadequate clinical placement opportunities. Patient safety helpful and effective". Additionally, while $65.0 \%$ of students agreed as the simulation can help in understanding the concepts which will be covered by it, only $3.3 \%$ of them disagreed. teaching methods used in this simulation were

issues, as simulation, allow health care practitioner to acquire the skills \&experience required to protect patient safety. ${ }^{[28]}$

The present study is significantly supported through research hypothesis, which directs our attention to stress the importance and utilization of simulation in the education for improving students' achievement, performance, and satisfaction regarding labor process and enhancement of the students' clinical skills.

Regarding characteristic of the students, the findings of the present study revealed that nursing students for both study \& control group, respectively, were in age ranged from 20-23 years with mean age $21.43 \pm 1.98 \& 21.04 \pm 1.46$, respectively. This finding is in accordance with Oh (2015) who conducted a study to determine the effects of simulation-based training in the learning outcome of nursing students and founded that the mean age of them was 21.44 years old; more than half $65.27 \%$ of the students were aged 21 years old. ${ }^{[29]}$

Moreover, more than half of the participant students were had technical health institute \& nursing institute; $53.3 \% \& 56.7 \%$ and most of them were from rural areas; $43(71.7 \%) \& 42$ (70.0\%); (study \& control group, respectively). This result is in line with Hassan etal, (2015) who studied the impact of technology-enhanced learning and teaching on the knowledge, attitude and practice of maternity and newborn health nursing students in Beni-Suef university and 
found that, of their sample, 77 (64.2\%) were living in rural districts. ${ }^{[30]}$

There was no statistically significant difference (pre-intervention) between study and control group regarding their theoretical knowledge about physiology and process of labor. This finding was supported with Saied (2017) who conducted a study, to evaluate the effect of using some simulation-based scenarios on the pediatric nursing students and documented that there was a significant difference between the pretest $\&$ the posttest knowledge scores. ${ }^{[31]}$ This may be due to lack of knowledge related to labor because most students didn't study this content in the previous curriculums.

Pre-intervention, it is surprising to find that the majority of participant students had incorrect and inadequate theoretical knowledge, regarding both process \& physiology of labor, although an acceptable percentage of them had studied this module previously in the technical institute of nursing $(53.3 \%$ \& $56.7 \%)$. This result is in accordance with Hassan etal (2015). ${ }^{[30]}$ This may be attributed to that students forgot the previously studied module as they didn't complete their recruitment process in the Ministry of health. Otherwise, in postintervention vise-versa was observed with statistical difference between study \& control group ( $<<0.001)$. The present study indicated that studied groups achieved highly statistical significant difference regarding their knowledge about labor lecture contents as the definition of normal labor, the difference between true and false labor pains, stages of labor, mechanism of labor and characteristic of uterine contractions. This result was matched with Omer (2016) who conducted a study, to explore the perception of 117 nursing students on their satisfaction and self-confidence after clinical simulation experience and, who reported improvement of knowledge because methods used in the simulation were effective and gave them clear ideas of what is expected from them. These knowledge acquisition abilities improve their self-confidence. ${ }^{[16]}$ This reflects the effect of the simulation model of teaching.

As well as regarding knowledge related to practical skills of stages of labor (preintervention), the present study revealed that there was no statistically significant difference between study and control groups regarding the aim of abdominal, vagina and perineal care, definition, value and components of partogram and signs of fetal stress. This finding is supported by Podlinski (2016) who conducted a study, to evaluate the effect of simulation training on nursing students' content exam score and found that may limit the nursing student's ability to learn and develop the necessary skills. ${ }^{[32]}$ This may be due to a lack of knowledge about the practical skills of labor modules. In addition, these findings were congruent with Aghaet al, (2015) who conducted a study, to evaluate medical students' satisfaction with simulation-based learning strategy", who indicated that there was high knowledge satisfaction with learning by the clinical simulation and that learner's confidence in their skills. ${ }^{[33]}$ On the other side, post-intervention, the current study revealed a highly statistically significant difference between study \&control group regarding knowledge about the practical skills during the process of labor including previously mentioned items. In this respect, Pantelidis, et al (2016) who conducted a study for evaluating the general educational environment of the course, as well as the skills and knowledge acquired by the participants, who founded that students improved their clinical knowledge and their ability to take action by diagnosing and intervening. As demonstrated by the pre/post- MCQs test, students performed better after the completion of the seminar. ${ }^{[34]}$ This may be due to students of the simulation group had given a chance for demonstration and make a mistake and redemonstration and correction of their mistakes that had led to gaining the confidence of improving practical skills.

Generally, the present study revealed a great difference between study \& control groups regarding their total knowledge pre/postintervention. It isn't surprising to find the majority of both study (86.7\%) and control $(84.3 \%)$ group had inadequate knowledge regarding the process of labor in preintervention phase. This is acceptable as most of them were secondary schools and didn't study this module previously. Otherwise, postintervention, our results illustrate a progression of total adequate knowledge of both study $(94.3 \%)$ and control (50.0\%) group. The achievement in both groups can be declared by even traditional methods of teaching will get knowledge for students. However, achievement 
was a highly satisfactory score in the study group; a high progression of total adequate knowledge of the study group $(94.3 \%)$ after intervention phases, associated with high regression of inadequate one (5.7\%), compared to control group $(50.0 \% \& 50.0 \%$, respectively). Of course, it attributes to the effect of intervention with simulation. This result agrees with Simko, et al, (2014) who conducted a study to "discover if participation in a mock code with a simulation manikin would result in increased knowledge of nursing students as well as a safe way to learn nursing interventions required during a code", and reported that scores were significantly higher in the post-test than the pretest overall, for the traditional undergraduate \&second degree students. The post-test scores were significantly higher for the $2^{\text {nd }}$ degree students than the traditional undergraduates. The simulation experience is truly a safe environment for the nursing student to learn the nursing interventions needed during a real code situation. This finding may be due to the increase of retained students' information and skills from study course. ${ }^{[35]}$

Simulation is an innovative and technologically advanced teaching and learning approach that combines a problem-based approach with experiential learning. The student learns through 'doing' and 'experiencing', utilizing their knowledge base, psychomotor skills and clinical decision making based on the information before them. ${ }^{[36]}$ The present study illustrated that the distribution of mean score of studied sample practice regarding labor procedures immediately $\left(1^{\text {st }}\right.$ trial) at the re-demonstration phase) and ( $2^{\text {nd }}$ trial $)$ at the clinical area evaluation phase had a statistically significant difference regarding their practical skills during process of labor (including perineal care, abdominal examination, vaginal examination, handling, assessment of fund us, placenta examination and newborn physical assessment). This may be due to improve student knowledge and retain information gained from lecturer and practical re-demonstration of the labor skill. However, the mean score of studied sample practice regarding labor procedures at the clinical area evaluation phase ( $2^{\text {nd }}$ trial) had a highly statistically significant difference regarding their practical skills during the process of labor. This may be due to that, the students' performance level was increased by the application of integrated training (stimulation videos and Noelle doll).
The mean score of studied sample regarding average practice score about labor procedures of both phases of assessment revealed the achievement was better in the study group than control one. A statistically differences found ( $p$ $=0.001)$. Moreover, the results present study revealed a highly statistically significant difference between study and control groups regarding their total practices pre/postintervention phase $(\mathrm{p}=0.001)$. Our results revealed that the majority of both study $(86.7 \%)$ \&control (83.3\%) group had inadequate \&unsatisfactory practical skills regarding stages of labor in the pre-intervention phase. This was expected as they may be didn't practice in the clinical areas previously. Otherwise, postintervention, our results illustrate a progression of total adequate practices of both study (93.3\%) and control (50.0\%) group. However, achievement was a highly satisfactory score in the study group; a high progression of total adequate practices of the study group (93.3\%) after intervention phases, associated with highly regression of inadequate one (6.7\%), compared to control group (50.0\% \& 50.0\%, respectively). A highly statistical significant difference $(\mathrm{p}=$ 0.001). This is supported by Bezyack (2007) who mentioned that simulation is potential tools that help the nursing students to practice in a real environment. ${ }^{[37]}$ It is a teaching strategy that provides students with an artificial representation of a complex real life for enabling them to learn in a safe environment. It offers the opportunity for students to improve the intended learning outcomes such as clinical skill performance, knowledge acquisition, clinical reasoning ability and student satisfaction. ${ }^{[37]}$

This results supported by Zarifcanaiey, et al, (2016) who conducted study to compare the effect of integrated training (simulation and critical thinking strategies) and the simulationbased training on performance level at critical thinking ability of nursing students, who founded that the experimental group obtained higher performance score significantly different than control group due to positive effect of using integrated methods on critical practice, problem solving skills, clinical efficacy, academic achievement, and clinical competence. $^{[38]}$ This may be explained by increase the students' performance level by application of integrated training (stimulation videos and Nolle doll). This is, also, in accordance with Edgar Dale's or the NTL's 
Pyramid of Learning as cited by researchers as the pyramid illustrated that people are able to learn $10.0 \%$ of what they read, $20.0 \%$ of what they hear, $30.0 \%$ of what they see, $50.0 \%$ of what they see/hear (demonstrate, apply \& practice), and $90.0 \%$ of what he does (simulate $\&$ model). ${ }^{[39-41]}$ (see Figure3).

Finally, regarding student's satisfaction about simulation method, the result of this study showed that slightly more than three-quarter of students of the studied sample agree with "the simulation provide student with a variety of learning materials \& activities to promote the learning curriculum". While a minority of them disagree with "help in understanding the concepts converted in the simulation. This may be attributed to the students in the simulation sessions take an opportunity for performing procedures on mannequins in a simulation lab and seeing videos about labor procedures (abdominal examination, vaginal exanimation, perineal care, placental examination, and newborn physical assessment). The result of this study was congruent with Mould, et al, (2011) who assess the effect of simulation on student satisfaction and confidence, who reported that a higher learner satisfaction with learning by clinical simulation and the learner confidence in their skills. ${ }^{[42]}$ In addition, omer (2016) reported that using simulation as a strategy for clinical education promote student satisfaction with their learning and improve self-confidence. Simulations prepare the student to for real-life experience and speed the transition to a professional career. ${ }^{[16]}$ Hall, (2013) supporting the present study finding, by evaluating the effect of simulation-based education on baccalaureate nursing students' satisfaction and reporting that the students were very satisfied with the simulation learning activity. ${ }^{[43]}$

The current study emphasized that, utilized of simulation on students' achievement on labor modules as simulation training provides the nursing student with opportunities for active involvement in learning, enables nursing students to gain new knowledge and build upon previous skill. Simulation training also provides self-paced learning and affords nursing students the opportunity to make mistakes and learn from them, which cannot be accomplished in the clinical setting. Moreover, simulation training can provide standardized learning experiences to all nursing students by enabling active experience. This guides our attention to utilize simulation for students in education.

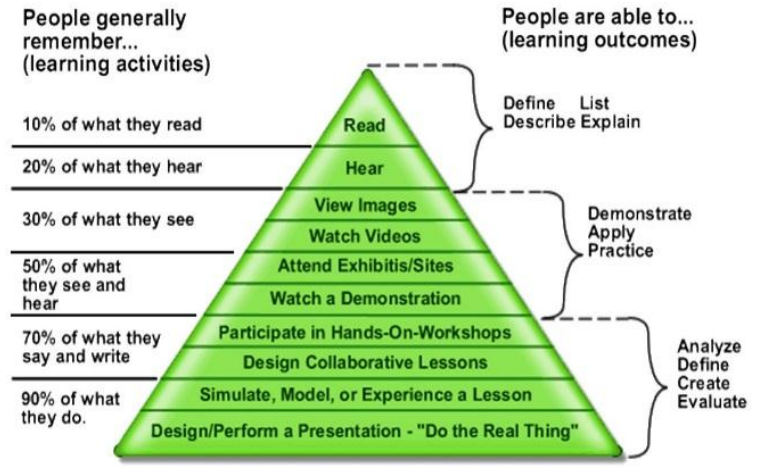

Figure3. Edgar Dale's or the NTL's Pyramid of Learning ${ }^{[39]}$

\section{CONClusion}

Simulated delivery room classes were an effective training approach; they provide students with practices that result in significantly higher practical achievements and higher satisfaction scores compared to the conventional training. Moreover, there was a high statistical significant difference between study and control groups regarding their knowledge and practices regarding labor. Additionally, maternity nursing students attain a highly level of satisfaction in learning regarding simulation activities. The above-mentioned findings support the study hypothesis (The students who learn the labor modules through simulation will have significantly higher achievement scores \& satisfaction level compared with those who learn through the traditional classroom-based teaching.

\section{RECOMMENDATION}

- Maternity nursing students should be provided with a variety of simulation-based education on maternity nursing skills to enhance thesis practices, satisfaction, and self-confidence.

- Simulation-based teaching should be integrated into the practical training for students before their contact with actual woman in the labor units with clear connections toward achievement of student learning outcomes.

\section{REFERENCES}

[1] Peisachovich, E., Gal, R., \& Johnson, S. Experiences of undergraduate nursing students of standardized patient methodology in their transition to nursing practice in Ontario Canada. Journal of Nursing Education and Practice, 2016; 7(3): 1-9. doi:10.5430/ jnep.v7n3p1

[2] Montagna S., Omicini, A. Simulation \& MultiAgent Systems an Introduction Autonomous 
Systems SistemiAutonomi, Universita di Bologna, 2016; 10.

[3] Gray, J · Rumpe, B. Models in simulation, University of Alabama, Tuscaloosa, Alabama, USA, Aachen, Germany, 2016; 15: 605-607

[4] California Board of Registered Nursing. California code of regulations. Article 3. Pre licensure nursing programs.

[5] Arthur, C., Jones, T. \&Kable, A. Quality indicators for design and implementation of simulation experiences, Nurse Educ. Today, 2015; 33 (11): 1357-1361.

[6] Aebersold, M., \&Tschannen, D. Simulation in Nursing Practice: The Impact on Patient Care, the online journal of issues of nursing, 2013; 18(2): 1 .

[7] Adamson, K.A. Evaluation tool and metrics for simulation, clinical simulation in nursing education: advanced concept, trends and opportunities, 1st e, Wolters Kluwer, Philadelphia, 2014; 145:164.

[8] Valler-Jones, T., Meechan, R., \& Jones, H. Simulated practice: A panacea for health education, 2011.

[9] Larue, C., Bebin, J., \&Allard, 1. Simulation in preparation or substitution for clinical placement, journal of nursing education and practice, 2015; 5(9): 132.

[10] Ricketts, B. The role of simulation for learning within pre-registration nursing education: A literature review. Nurse Education Today, 2011; 31: 650-654.

[11] Bandopadhyay, S., \& Bhattacharya, R. Discrete and Continuous simulation theory and practice, 1st ed, London, 2014; 14:16.

[12] Society for Simulation in Healthcare. About simulation, 2015. Retrieved from http://www.ssih.org/About-Simulation. Accessed on august 2017.

[13] Sauls, D. Nurses attitude toward provision of care and related outcomes. Nursing research, 2011; 56(2): 117:123.

[14] Shellenbarger, T., \& Edwards T. Nurse Educator Simulation: Preparing Faculty for Clinical Nurse Educator Roles. Clinical Simulation in Nursing, 2012; 8(6): 249-255.

[15] Nasr, E., Hassan, H. Association between quality of family planning services and client's satisfaction level in maternal and child health centers in Port Said city. Journal of Nursing Education and Practice. 2016; 6(1): 85-99. doi: 10.5430/jnep.v6n1p85

[16] Omer, T., \&Marzouk, T. Effectiveness of simulated delivery room classes on practical achievement and satisfaction of maternity nursing students, Woman's Health and Midwifery Nursing Department, Faculty of Nursing-Mansoura): Nursing Students'
Perceptions of Satisfaction and Self-Confidence with Clinical Simulation Experience, Journal of Education and Practice, 2015; 7 (5):131-136.

[17] Goldsworthy, S., \& Graham, L. Simulation simplified: A practical handbook for nurse educator, Philadelphia, Lippincott Williams and Wilkins, 2013: 525.

[18] Jeffries, P. Simulation in nursing education: From conceptualization to evaluation. New York, National League for Nursing, 2007: http://akoaotearoa.ac.nz/communities/collabora tion-clinical-simulation-leading-way.

[19] Jeffries, P. Signs of maturity, Simulation are growing and getting more attention. Nursing Education Perspectives, 2015; 36 (6): 358-359. http://nlnjournals.org/doi/pdf/10.548015365026-36.6358.

[20] Crown, W. Potential application of machine learning in health Outcomes research and some statistical cautions. Value Health, 2015; 18: 137.

[21] Mcgahie, W., Issenberg, B., \& Pertusa, E. A critical review of simulation- based medical education research, Mosby Elsevier, Philadelphia, 2010: 51-55.

[22] Todd, M., Hawkins, K., Hercinger, M., Manz, J., Tracy, M., \& Iverson, L. Creighton Competency Evaluation Instrument, 2014. Retrieved from https://nursing.creighton.edu/ academics/competency-evaluation-instrument Accessed on 25 Jun 2017.

[23] Passiment, M., Sacks, H., \& Hunge, G. Medical simulation in medical education: Result of an AAMC survey, Washington, DC: Association of American Medical Collage. 2011. https://en.oxforddictionaries.com/definition/ach ievement

[24] Raymond, C. Do Role-Playing Simulations Generate Measureable and Meaningful Outcomes? A Simulation's Effect on Exam Scores and Teaching Evaluations, International Studies Perspectives, 2010; 11(1): 37-51.

[25] Guy, R., Lownes, M., \& Jackson, F. The Use of Computer Simulation to Compare Student Performance in Traditional Versus Distance Learning Environments State University, USA, 2015; 12: 95.

[26] Koh, C., Tan, H., Tan, K., Fang, T., Fong, F., Kan, D., Lye, S., \& Wee, M. Investigating the effect of 3D simulation-based learning on the motivation and performance of engineering students. Journal. 2010.

[27] Richardson, K., \& Claman F. High Fidelity Simulation in Nursing Education a Change in Clinical Practice. Nursing Education Perspective, 2014; 35: 125-127.

[28] Oh, H., Effect of simulation based training on the learning outcome of nursing students'. 
Advanced science and technology letters, 2015; 88: 251-255.

[29] Hassan, H., Helmy, H., Mohamed, A. The Impact of Technology Enhanced Learning and Teaching on the Knowledge, Attitude and Practice of Maternity and Newborn Health Nursing Students in Beni-Suef University. International Journal of Advanced Research, 2015; 3(11): $643-649$.

[30] Saied, H. The Impact of Simulation on Pediatric Nursing Students' Knowledge, Selfefficacy, Satisfaction, and Confidence, 2017; 8 (11).

[31] Podlinski, L.A. The Effect of Simulation Training on Nursing students'Content Exam Scores, Walden University, 2016: 21-25.

[32] Agha S., Alhamrani A., Khan M. Satisfaction of Medical Students with Simulation based learning, Saudi Medical Journal, 2015; 36: 731736.

[33] Pantelidis, P., Staikoglou, N., Paparoidamis, G., Drosos, C., et al. Medical students' satisfaction with the Applied Basic Clinical Seminar with Scenarios for Students, a novel simulationbased learning method in Greece, J EducEval Health Prof, 2016; 13: 13, 5.

[34] Simko, L., Henry, R., McGinnis, K., \& Kolesar, A. Simulation and mock code: A safe way for nursing students to learn, Journal of Nursing Education and Practice, 2014; 4(7): 95.

[35] Kim, J., Park, J., \& Shin, S. Effectiveness of simulation-based nursing education depending on fidelity, BMC Medical Education, 2016; 16: 152 .
[36] Bezyack, M. Simulation help RNs home skill nursing spectrum Fall critical care specialty guide, 2007: 68-70.

[37] Zarifcanaiey, N., Amini, M., \& Saadat, F., A comparison of educational strategies for the acquisition of nursing students' performance and critical thinking, BMC medical education, 2016; 16: 294, 1-7.

[38] Thalheimer W. Debunk This: People Remember 10 Percent of What They Read. Thursday, March 12, 2015.

[39] Hassan, H., Nasr, E. Improving nurses' knowledge and skills regarding tocolytics for inhibiting preterm labor. Clinical Nursing Studies. $\quad 2017 ; \quad 5(1)$ : $1-12$. https://doi.org/10.5430/cns.v5n1p1.

[40] Hassan, H. Effectiveness of a structured teaching program on anxiety and perception regarding toxoplasmosis among seropositive pregnant women in Northern Upper Egypt. Clinical Nursing Studies. 2018; 6(1):1- 19. https://doi.org/10.5430/cns.v6n1p1.

[41] Mould, White, H., \& Gallagher, R., evaluation of critical care simulation series for undergraduate nursing students, contemporary nurse, 2011; 38:180-190.

[42] Hall R., Rachel M. Effects of High Fidelity Simulation on Knowledge Acquisition, SelfConfidence, and Satisfaction with Baccalaureatez Nursing Students Using the Solomon-Four Research Design. Electronic Theses and Dissertations. 2013.

Citation: Noha Hassan Abd-Elfattah, Galal Ahmed EL-Kholy, Amal Ahmed Hassan, Hanan Elzeblawy Hassan. Call for Activation of Simulation Modules for Nursing Students' Achievement and Satisfaction of Normal Labor: A Quasi-Experimental Study, ARC Journal of Nursing and Healthcare. 2018; 4(2): 24-39. doi: dx.doi.org/ 10.20431/2455-4324.0402004.

Copyright: (C) 2018 Authors. This is an open-access article distributed under the terms of the Creative Commons Attribution License, which permits unrestricted use, distribution, and reproduction in any medium, provided the original author and source are credited. 